\title{
The Categorization of Dou（都） in Chinese: A Study from a Cross-linguistic Perspective
}

\author{
Zhang Ying \\ Harbin Institute of Technology, Shenzhen \\ yingzhang@hit.edu.cn
}

\begin{abstract}
Compared with prototypical universal quantifiers in other languages of the world, dou in Mandarin Chinese presents more complicated semantic behaviors. One of the most disputed issues is what are the relations between dou expressing "universal quantification" (UQ) and dou expressing "scalar trigger" (SCA). First-hand data that comes from 40 languages demonstrates that Mandarin Chinese is the only language that employs the same form for "universal quantification" and "scalar trigger". The empirical evidence strongly suggests that UQ dou and SCA dou are different, and the two functions UQ and SCA lack universal conceptual correlations. The special polysemous behavior of Mandarin dou, is proved to come from two language-specific reanalysis processes in dou's diachronic development which also supports the two-dou claim. The study thus instantiates how a cross-linguistic perspective provides insights to explain long-standing language-particular issues. Besides, it is also argued that the crosslinguistic approach is promising in predicting if a future research is on a right track as it can steer us through overgeneralization and undergeneralization.
\end{abstract}

\section{Keywords}

dou - universal quantification - scalar trigger - cross-linguistic comparison

\section{Introduction}

The adverb dou in Mandarin has long been an area of fascination due to its complex and distinctive syntactic and semantic properties. Until very recently, discussions on Mandarin dou still took center stage. One of the most disputed topics is how many dous there are in Chinese, and why and how the different meanings are subsumed under one grammatical morpheme in Chinese. Xiandai Hanyu Babaici ( 《現 代漢語八百詞》）, as in many other descriptive works, lists the following three uses of dou.

\section{Universal Quantification}

(1) 他們都是老師。

tāmen dōu shì lăoshī

3PL DOU COP teacher

'They are all teachers.' 


\section{Scalar Trigger}

(2) 這麼簡單的問題, 三歲小孩都知道。

zhème jiăndān de wèntí sān suì xiăo hái dōu zhīdào

so simple AUX question three-year small child Dou understand

'So simple a question that even a three-year-old child can understand (it).'

\section{Already \\ （3）老師都走了，他才來。 \\ lǎoshī dōu zǒu le tā cái lái \\ teacher DOU go PFV 3SG not until come \\ 'He did not come until the teacher had already gone.'}

A considerable amount of research proposes that there is only one semantic characterization of dou (Lee 1986; Cheng 1995; Jiang 1998; Pan 2006). In these studies, it is argued that both the readings of "scalar trigger" and "already" could be regarded as extensions of the first meaning "universal quantification" in particular contexts. ${ }^{1}$

However, other studies reveal that the first use is more objective whereas the latter two uses contain subjective evaluations (Wang 1999, 2001; Jiang 2003; Zhang 2005). Therefore, it is argued in these studies that there are two subtypes of $d o u$, in which $d o u_{1}$ carries the function of "universal quantification" as illustrated by (1) and dou denotes a more subjective meaning of "being abnormal or inappropriate" as shown by (2) and (3). As for the relation of these two uses of dou, some studies describe the "scalar trigger" use as a pragmatically reinforced subtype of the "universal quantification" use (Xiao 2005; Jiang 2011) while others hold an opposite view about this and argue that the "universal quantification" use is not embedded in its "scalar trigger" use (Shank 2004; Chen 2008).

Other studies compromise between the above two opinions, putting forward the claim that there is only one dou in Chinese, but it can be attributed to two types according to the syntactic/semantic differences (Jiang and Pan 2013; Li 2013; Shen 2015). The two subtypes of dou in these studies basically correspond to $d o u_{1}$ and $d_{0} u_{2}$ as categorized by the second approach. ${ }^{2}$

In fact, if we exclusively rely on internal observations within a single language, it would be rather difficult to evaluate which view among the above-mentioned three fares the best. The first approach emphasizes the consistency among the different uses whereas the second emphasizes their differences. Although the third approach captures more behaviors of $d o u$, it is largely a rearrangement of the ideas previously known, with no new evidence provided.

To solve this long-standing dilemma, we need to take recourse to external evidence-regularities gained through cross-linguistic comparison. If the different functions ${ }^{3}$ delivered by dou are demonstrated to reflect some universal conceptual connections (i.e. the functions are repeatedly expressed by

1 Jiang (1998) applies Relevance Theory to prove that the "scalar" meaning and the "already" meaning are produced by the whole structure that contains dou rather than dou itself. What dou performs in these two contexts could both be subsumed into the first meaning "universal quantification."

2 Jiang and Pan (2013) further differentiate two subcategories of $d o u_{1}$ and $d o u_{2}$ respectively according to whether there is an "exclusive" reading attached.

3 As demonstrated by reviewing the previous studies on the categorizing issue of dou, the core of the debate is whether the non-scalar use of dou ("universal quantification") and the scalar uses of dou ("scalar trigger" and "already") should be 
one grammatical morpheme across different languages), it will suggest that at the level of human conceptualization, they are intrinsically interconnected and thus subsumable, thereby justifying the oneness of dou in Chinese. However, if the functions are proved to lack a universal correlation (the functions tend to be expressed by different grammatical morphemes in different languages), chances are high that different dous should be identified.

In this research, we will examine the conceptual correlations of "universal quantification" and "scalar trigger" by comparing the cross-linguistic data collected from 40 languages, and apply the insight obtained from cross-linguistic comparison to solving the long-standing categorization issue of dou in Chinese.

If we compare Chinese dou with its counterparts in other languages, one of the most striking differences is that $d o u$, as a universal quantifier in Chinese, can also take over the function of "scalar trigger." By contrast, the universal quantifiers in other languages cannot extend their functions to "scalar trigger." The "scalar trigger" function in these languages is often delivered by another group of grammatical morphemes - "additive particles." For instance, in the Zhuang language, the function of "scalar trigger" is expressed by the word hix, but hix is not the word used to express "universal quantification," but a word that would be simply rendered in English as also-an expression for the function of "additive focus." Therefore, we feel obliged to take the function of "additive focus" into consideration as well to prepare the ground for further cross-linguistic comparisons. In the following, the three related functions"additive focus," "scalar trigger" and "universal quantification" — will be explained in detail.

\subsection{Additive Focus (ADD)}

"Additive focus" is commonly expressed in English by means of too, also and as well' (Gil 2004). It means to add a new circumstance to the antecedent, in order to show consistency. In nature, it is an existential operator.

\section{(Jino: Tibeto-Burman; Sino-Tibetan)}

(4) nә le $^{55} a, y^{42} \operatorname{lo}^{33} l^{33} a$.

2SG go PRT 1SG ADD go PRT

'If you go, I will go too.'

This could be simply expressed as ' $\left[[\mathrm{you}]_{\text {targetı }}\right.$ go $] \wedge\left[[\mathrm{I}]_{\text {target2 }}\right.$ go $]$ ' and there is a consistency shown in between the two target members. Basically, the additive focus does not affect the truth value of the original sentence, but it does bring a presupposition that at least one of the alternative values under consideration in a context satisfies the same predicate. This alternative value could be made explicit like "you" in sentence (4), but could also be implicit, that is to say, existing in the context or in the mutual knowledge

differentiated or not. In this paper we will mainly address the relations between "universal quantification" and "scalar trigger." The function of "already" will be set aside in this paper with no harm. 
held by the speaker and the addressee. Discussions on additive focus particles, like König (1991: 62) and Shank (2004: 31), mainly focus on this presupposition, but we would like to point out further that apart from the existential presupposition it invokes, additive focus also suggests similarity between the alternative value and the focus that the additive particle introduces. In fact, for the most typical additive particle in Chinese, ye, its function is most widely accepted as "showing similarity (類同 )" (Ma 1982).

\section{$2.2 \quad$ Scalar Trigger $(s c A)$}

The concept of "scalar trigger" is sometimes called "scalar additive focus" (König 1991: 66), which is seen as a special case of "additive focus." In fact, "scalar trigger" also refers to an addition of focus, but the difference is that the individual that has been added is located at an extreme of a pragmatic scale. As argued by Fillmore, Kay, and O'Connor (1988) in the "scalar model," one uses an operator to trigger the highest/ lowest polarity so as to realize the pragmatic entailment. The higher on the scale the expression is located, the more informative it is, and thus it is easier to entail relevant expressions. For example:

(Lachi: Kra, Tai-Kadai)

(5) to $^{55} 6 \mathrm{O}^{44}$ tei $^{55}$ ljui $^{55} \quad \mathrm{vua}^{35}, \mathrm{li}^{44}$ tjou $^{55} \mathrm{sei}^{31} \quad \mathrm{la}^{31} \mathrm{6u}^{55} \mathrm{ljo}^{31}$.

past 1PL handicap very one CLF character even know NEG

'It was quite a handicap in the past that we didn't know even one word.'

By addressing the extreme situation, $l a^{31}$ triggers the extreme situation of the event of "not knowing a word," which is much more informative than those located lower in the scalar model, like "not knowing two/three ... words". It is easy to see that this sentence is equal to "we knew none of the words" in terms of truth value. Also, the example sentence actually contains the negative polarity item (NPI), which is one of the two types of what we called "scalar trigger" here. As suggested by Gast and van der Auwera (2011), different forms may be used to denote "scalar trigger" in affirmative contexts and in negative contexts, especially for languages in Europe. Therefore, another category that contains the positive polarity item (PPI) is also identified in this study. For instance:

\section{(Dong: Kam-Tai; Tai-Kadai)}

(6) lieen yaoc nyac buh haemk.

even ISG 2SG even ask

'You ask even me.'

To lay some groundwork for further discussion, we would like to differentiate two subtypes of PPI. As is well known, the implied meaning of a sentence can be divided into the conventional implicatures and the conversational implicatures. As the former have been conventionalized in the grammaticalization process, it is not defeasible by adding an opposite context. The latter have not been conventionalized, and therefore the implicatures could be cancelled. The P PI in our study only refers to the Conventional PPI but not Conversational PPI.

\subsection{Universal Quantification (UQ)}

The term "universal quantification" here is used in the same sense as generally accepted in formal semantics. It shows that a property/action is satisfied by every member of the quantified domain. 
(Jing: Mon-Khmer, Austro-Asiatic)

(7) kuj $^{2}$ qau $^{1}$ kuj $^{3}$ la:i $^{6} \quad$ joi $^{2}$

everyone all come PFV

'All have come.'

In the above example, $k u \eta^{3}$ marks the action lai $i^{6}$ as one undergone by all participants expressed by $k u \eta^{2} \eta a u^{1}$, reflected in the English translation of "all"; therefore, all the participants in the domain possess the same property of the predicate. As is also the case in the categorizing practice in formal semantics, there are two instantiations of universal quantification: those with the property of totality/maximality and those with the property of non-totality/non-maximality. ${ }^{4}$ The former includes expressions like English every/each, which allow no exception to the quantification of all the members. In contrast, the latter has more tolerance of exceptions, like Chinese dou, which does not always apply the exhaustivity quantification to the NP (Wu and Tao 2014; Xu 2014).

\section{Cross-linguistic Representation Patterns}

In this section, we will first introduce the procedure and example sentences that we adopted to investigate the 40 languages and then present the different connecting patterns by analyzing the cross-linguistic data received.

\subsection{Investigating Procedure and Language Data}

The investigating procedure is basically onomasiological. We will start from the three concepts of "additive focus," "scalar trigger" and "universal quantification," and try to figure out their formal expressions in different languages. After this, the different correlation patterns of the concepts and the forms will be compared in order to see in what fashion these concepts are correlated.

For the three concepts that we have analyzed above, example sentences have been designed to help the interviewees to find the counterparts in their mother tongues. Most of the examples are extracted from instantiations of the concepts in reference grammars, and, as we will see, more than one example sentence is offered under each of the concepts so as to capture all the syntactic environments in which the concepts may occur.

\section{Additive Focus}

i. If you go, I will go too.

ii. My younger brother is also sick.

Although in English different words are employed to show the different syntactic levels of the focus, there is no such difference in most other languages in my data sample.

4 There are of course other ways to convey universal quantification, such as reduplicated classifiers in Mandarin like 人人 renren, 'everyone.' Such expressions are irrelevant to our theme and will be left unaddressed in this study. 


\section{Scalar Trigger}

i. He is so poor that he doesn't even have a place to sleep.

ii. Even a small child knows this.

iii. She gave him lots of things, even this/this too.

In light of the detailed canvass of scalar triggers provided in the previous section, we find that sentence i is an example of an NPI polarity trigger while sentence ii is an instance of a PPI polarity trigger. As for sentence iii, the alternatives of "even this" and "this too" are meant to confirm whether the PPI polarity trigger is a conventional one or a conversational one. When the investigation proceeds to this item, a more detailed context is offered by the interviewer to further differentiate the two types of implicatures.

\section{Universal Quantification}

i. Everyone has come.

ii. They all need to work hard.

iii. The playground is full of young people.

From sentence i to sentence iii, the restriction on the totality property of the quantified scope gets progressively looser. In this way, we are trying to provide all the possible environments for the maximality universal quantifiers and non-maximality universal quantifiers in different languages.

Based on the above-mentioned procedures and examples, we interviewed more than 40 interviewees about their mother tongues at UCLA and BLCU, ${ }^{5}$ and collected data from 40 languages that come from 10 language families. The 40 languages are comprised of 14 Indo-European languages, 8 Sino-Tibetan languages, 6 Niger-Congo languages, 3 Austronesian languages, 3 Turkic languages, 2 Tai-Kadai languages, 1 Austroasiatic language, and 1 Afro-Asiatic language as well as Korean and Japanese. Table 1 offers a breakdown of the sources of the language data.

3.2

\section{Three Types of Cross-Linguistic Representation Patterns}

Now let us look into how the 40 different languages use different forms to express the three concepts. There are mainly four types of representations found in the 40 languages we investigated.

\section{Representation Pattern 1}

The three concepts "additive focus," "scalar trigger" and "universal quantification" are coded separately by three distinct grams in 17 languages in our data pool.

To facilitate further comparisons with other types, we can diagram this type of representation by using the blocks to show the allocation pattern as shown in Fig. 1:

The 17 Type 1 languages and their respective forms for the three concepts are shown in Table 2:

5 UCLA and BLCU stand for "University of California, Los Angeles" and "Beijing Language and Culture University" respectively. 
TABLE 1

Data sources by language families and branches

\begin{tabular}{|c|c|c|}
\hline \multirow[t]{7}{*}{ Indo-European } & Baltic & Latvian \\
\hline & Balto-Slavic & Russian \\
\hline & Creole & Antiguan Creole \\
\hline & Germanic & German \\
\hline & Hellenic & Greek \\
\hline & Indo-Iranian & Bengali, Hindi, Persian, Tajik, Urdu \\
\hline & Italic & $\begin{array}{l}\text { French, Italian, Portuguese, } \\
\text { Spanish }\end{array}$ \\
\hline \multirow[t]{3}{*}{ Sino-Tibetan } & Chinese & $\begin{array}{l}\text { Cantonese, Jin dialect, Min (Taipei), } \\
\text { Min (Yun'ao), Southwestern } \\
\text { Mandarin, Wu dialect }\end{array}$ \\
\hline & Lolo-Burmese & Nuosu (Yi language) \\
\hline & Tibeto-Kanauri & Tibetan \\
\hline Niger-Congo & Atlantic-Congo & $\begin{array}{l}\text { Ghomálá, Kinyarwanda, Pular, } \\
\text { Setswana, Shona, Swahili }\end{array}$ \\
\hline Austronesian & Malayo-Polynesian & Indonesian, Malay, Tagalog \\
\hline \multirow[t]{3}{*}{ Turkic } & Karluk & Uzbek \\
\hline & Kipchak & Kazakh \\
\hline & Oghuz & Turkish \\
\hline Tai-Kadai & Tai & Thai, Zhuang \\
\hline Austroasiatic & Vietic & Vietnamese \\
\hline Afro-Asiatic & Semitic & Arabic \\
\hline Koreanic & & Korean \\
\hline Japonic & & Japanese \\
\hline
\end{tabular}

Additive Focus

Scalar Trigger

Universal Quantification

FIgURE 1 Distributive Pattern of Type 1

Apart from the 17 languages listed in Table 2, German also uses different lexical forms to code the different notions individually; however, it goes deeper for the concept of "scalar trigger" and tends to use different words to express the PPI and NPI scalar triggers. For the former, selbst is used whereas for the latter, nicht einmal is employed. For the current purpose, we will categorize German into Type 1 as all these grams in German are mono-functional, as in the other Type 1 languages. Therefore, for Type 1, we 
TABLE 2 Data of Type 1

\begin{tabular}{|c|c|c|c|c|}
\hline Language & Language Family & $\begin{array}{l}\text { Gram for Additive } \\
\text { Focus }\end{array}$ & $\begin{array}{l}\text { Gram for Scalar } \\
\text { Trigger }\end{array}$ & $\begin{array}{l}\text { Gram for Universal } \\
\text { Quantification }\end{array}$ \\
\hline Turkish & Turkic & de & bike & hepsi \\
\hline French & Indo-European & aussi & meme & tous \\
\hline Greek & Indo-European & episis & akoma ke & oeo \\
\hline Latvian & Indo-European & ari & pat & visi \\
\hline Portuguese & Indo-European & também & mesmo & todo \\
\hline Russian & Indo-European & toje & daje & vsye \\
\hline Spanish & Indo-European & también & incluso & todos \\
\hline Antiguan Creole & Indo-European & anarl & eben & arl \\
\hline Thai & Tai-Kadai & duay & mai & thang \\
\hline Ghomálá & Niger-Congo & ie & bai & wai \\
\hline Pular & Niger-Congo & kadhi & haye & foppe \\
\hline Swahili & Niger-Congo & pia & hata & wote \\
\hline Arabic & Afro-Asiatic & aidan & hata & jamie \\
\hline Malay & Austronesian & juga & pun & semua \\
\hline Japanese & Japonic & mo & demo & mina \\
\hline Korean & Koreanic & do & la do & ta \\
\hline $\operatorname{Min}\left(\right.$ Yun'ao) ${ }^{6}$ & Sino-Tibetan & $a^{33}$ & sua $^{43}$ & $\operatorname{ham}^{33} \mathrm{e}^{33}$ \\
\hline
\end{tabular}

have 18 languages altogether, which constitutes 45 percent of the data sample. If we zoom in to see the difference in distribution among the language families, we find that, for the Indo-European family and the Niger-Congo family, the Type 1 languages occupy exactly half of the sample from the family, namely 7 out of 14 , and 3 out of 6 , respectively. But for the Sino-Tibetan language family, from which 8 languages/ dialects are sampled, only one language belongs to Type 1 .

\section{Representation Pattern 2}

There are 18 languages in our sample that use additive focus particles to express the concept of "scalar trigger" (including both the PPI scalar trigger and N PI scalar trigger).

The representation pattern is presented in Fig. 2:

The 18 languages and relevant data are shown in Table 3:

One language offers a slightly different picture from Pattern 2 - the Italian language. Fig. 3 shows how it differs from the typical Type 2 language.

6 The original characters of the three grams in Min (Yun'ao) are not clear. 


\begin{tabular}{|c|c|}
\hline Additive Focus & Scalar Trigger \\
\hline
\end{tabular}

FIgURE 2 Distributive Pattern of Type 2

TABLE 3 Data of Type 2

\begin{tabular}{|c|c|c|c|}
\hline Language & Language Family & $\begin{array}{l}\text { Word for Additive Focus } \\
\text { and Scalar Trigger }\end{array}$ & $\begin{array}{l}\text { Word for Universal } \\
\text { Quantification }\end{array}$ \\
\hline Bengali & Indo-European & -0 & sob \\
\hline Hindi & Indo-European & bhi & $\mathrm{sab}$ \\
\hline Persian & Indo-European & ham & hameh \\
\hline Tajik & Indo-European & ham & hamma \\
\hline Urdu & Indo-European & bhi & $\mathrm{sab}$ \\
\hline Kazakh & Turkic & da & barligi \\
\hline Uzbek & Turkic & ham & hamma \\
\hline Vietnamese & Austroasiatic & cũng & đều \\
\hline Kinyarwanda & Niger-Congo & na & bose \\
\hline Setswana & Niger-Congo & le & ba \\
\hline Shona & Niger-Congo & -wo & vese \\
\hline Zhuang & Tai-Kadai & hix & cung \\
\hline Indonesian & Austronesian & juga & semua \\
\hline Tagalog & Austronesian & ren & lahat \\
\hline Nuoso(Yi) & Sino-Tibetan & nyi & sa \\
\hline Tibetan & Sino-Tibetan & yang & ganga \\
\hline Wu dialect & Sino-Tibetan & $\mathrm{a}^{33}$ (也) & $\mathrm{ze}^{33}$ (儕) \\
\hline Jin dialect & Sino-Tibetan & $\mathrm{i} \varepsilon^{214}$ (也) & t6 $6^{\prime} \mathrm{yn}^{55}$ (全) \\
\hline
\end{tabular}

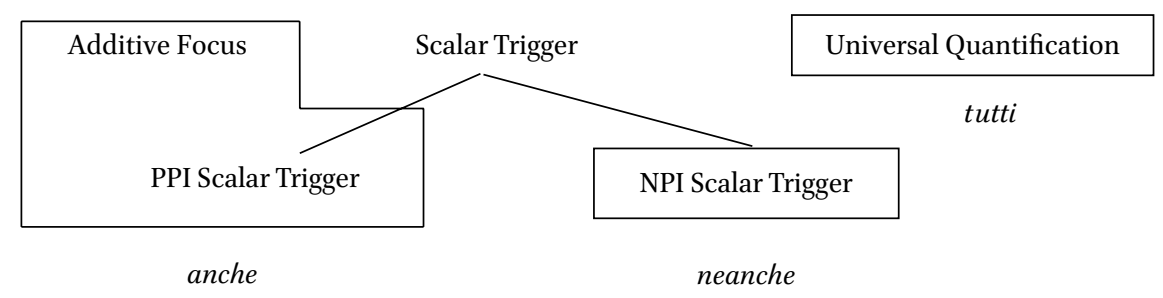

FIGURE 3 Distributive Pattern of Italian 
Italian is the same as the other languages listed in Table 3 in using a separate lexical item to code the concept of universal quantification. However, two different forms are employed in affirmative sentences and negative sentences respectively in expressing the concept of scalar trigger. As it also shows a strong connection between the notion of "additive focus" and that of "scalar trigger," it is categorized into Pattern 2 as well.

If Italian is included, we have a total of 19 languages belonging to Type 2 . These 19 languages constitute 47.5 percent of our language sample. In terms of different language families, for Indo-European languages and Niger-Congo languages, languages of Pattern 2 count for almost half of the sample from each language family, namely 6 out of 14, and 3 out of 6 respectively. If we compare the ratios of Type 1 and Type 2 in the two language families, the two categories are evenly divided in the sample languages. That is to say, for a language coming from the Indo-European family or the Niger-Congo family, there is approximately a $5^{0}$ percent chance that it uses three distinct forms to denote the notions of "additive focus," "scalar trigger" and "universal quantification"; and a $5^{\circ}$ percent chance that it employs the additive focus particle to denote the concept of "scalar trigger," or at least the "scalar trigger" in affirmative sentences, but a different form for "universal quantification."

However, among the eight members of the Sino-Tibetan family, four members show Pattern 2. All of them are non-Mandarin Chinese varieties; while Mandarin Chinese demonstrates a unique representation pattern-Type 3 .

\section{Representation Pattern 3}

There is only one example in our data pool that shows Pattern 3, namely the Southwestern Mandarin dialect spoken in Chongqing. In this dialect, the universal quantifier, which is identical in form to that in Standard Mandarin, can also be employed to express the function of "scalar trigger."

Pattern 3 can be represented in one schema as in Fig. 4:

\section{Additive Focus}

$$
\text { Scalar Trigger } \quad \text { Universal Quantification }
$$

FIGURE 4 Distributive Pattern of Type $3^{7}$

The most prominent feature of Type 3 is that an identical form is employed for the concepts of "scalar trigger" and "universal quantification," whereas in the previous two types, the two concepts are expressed by distinct forms.

Apart from the two sub-dialects of Mandarin Chinese mentioned above, the Min dialect spoken in Taipei is another example of Type 3 but with a slight deviation. It is different in that only the N PI scalar trigger can be expressed by the universal quantifier whereas the PPI scalar trigger shares the same form with the additive focus particle. The pattern can be illustrated as in Fig. 5 .

As the universal quantifier in this dialect does not exclusively express the function of "universal quantification" like those in the previous two categories, it can deemed as a special case of Type 3 .

$7 Y e$ in Mandarin Chinese can also express the NPI scalar trigger. The overlapping pattern of dou/ye in this function is worth pursuing in a separate study. 


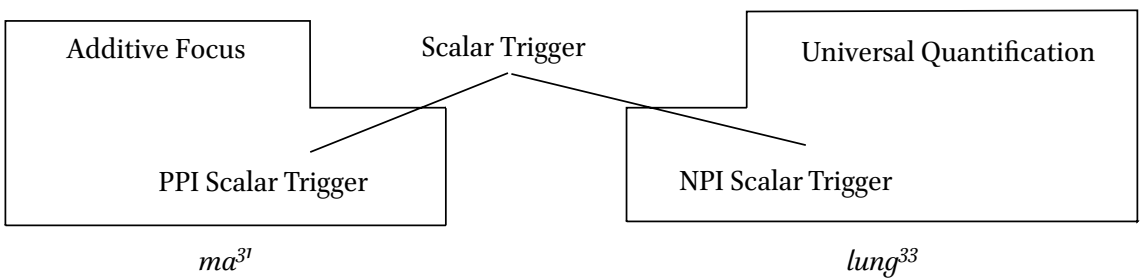

FIGURE 5 Distributive Pattern of Min Dialect in Taipei

\section{Representation Pattern 4}

We now turn to the last possibility, which is to express all the concepts with one and the same multifunctional gram. The only member in our data sample that falls into this type is the Yue variety of Chinese (Cantonese) in the Sino-Tibetan family. ${ }^{8}$ Cantonese dou is different from Mandarin Chinese dou in that it can also express the meaning of "additive focus." For example:

(8) Haih a, ngoh dou yauh heui.

is PRT ISG ADD have go

'That's right, I went too!' (Matthews and Yip 1994: 281)

Furthermore, the concept of "PPI scalar trigger," "NPI scalar trigger" and "universal quantification" can also be expressed by Cantonese dou, just like its counterpart in Mandarin Chinese.

PPI Scalar Trigger

(9) Gam yuhksyun dou yauh ge!

so ugly P.SCA exist PRT

'What could be so ugly?' (Matthews and Yip 1994: 283)

NPI Scalar Trigger

(10) Yat lap seng dou mouh.

one CLF sound N.SCA not-have

'There's not even a sound.' (Matthews and Yip 1994: 272)

Universal Quantification

(11) Leuhng ga dou leng.

Two CLF UQ nice

'They're both nice.' (Matthews and Yip 1994: 263)

Therefore, the representation pattern for Type 4 is much more concise than the previous ones as is shown in Fig. 6.

We can put aside the differences inside the concept of scalar trigger for now and have a general picture of the four types of cross-linguistic representations of the concepts "additive focus," "scalar trigger" and

8 Second-hand data from the reference grammar of the Lachi Language has also provided data which shows the pattern of Type 3 (Li 2000) 


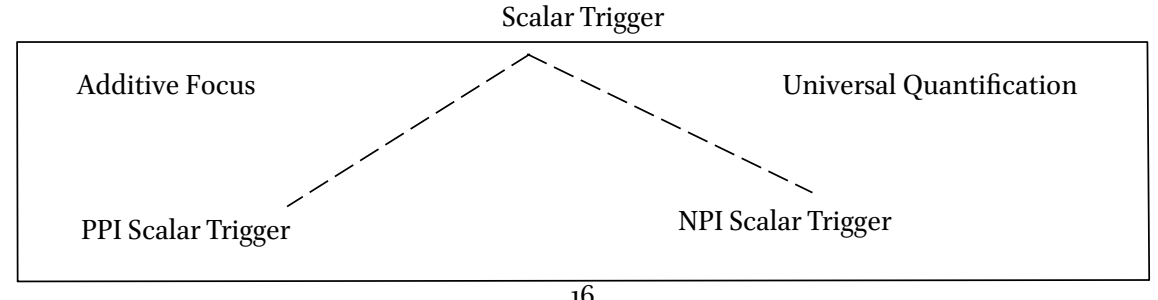

16

FIGURE 6 Distributive Pattern of Type 4 (Cantonese)

"universal quantification." Table 4 summarizes the contrast. (The three special cases which involve the differentiation of PPI and NPI are excluded for now.)

The above contrast clearly demonstrates that the universal quantifiers in Mandarin Chinese can take over one more function of "scalar trigger" and no other language behaves the same way. A fact that is worthwhile noting is that the situation in Mandarin Chinese is by no means representative of the Chinese language in this respect. Our investigation shows that many other regional varieties of Chinese do not take on the same polysemous behaviors as Mandarin dialects. For example, Wu dialects and Jin dialects

TABLE 4 Contrast among different cross-linguistic representations of the three concepts

\begin{tabular}{|c|c|c|c|c|c|c|}
\hline & \multicolumn{3}{|l|}{ Pattern } & Languages & Quantity & Ratio \\
\hline Representation 1 & ADD & SCA & UQ & $\begin{array}{l}\text { Antiguan Creole; } \\
\text { Arabic; French; Ghomálá; } \\
\text { Greek;Japanese; Korean; } \\
\text { Latvian; Malay; } \\
\text { Min (Yun'ao) } \\
\text { Portuguese; Pular; } \\
\text { Russian; Spanish; } \\
\text { Swahili; Thai; Turkish }\end{array}$ & $17 / 40$ & $42.5 \%$ \\
\hline Representation 2 & ADD & SCA & UQ & $\begin{array}{l}\text { Bengali; Hindi; } \\
\text { Indonesian; } \\
\text { Jin dialect; Kazakh; Kinyarwanda; } \\
\text { Nuoso (Yi); Persian; } \\
\text { Setswana; Shona; Tagalog; Tajik; } \\
\text { Tibetan; Urdu; Uzbek; } \\
\text { Vietnamese; } \\
\text { Wu dialect; Zhuang }\end{array}$ & $18 / 40$ & $45.0 \%$ \\
\hline Representation 3 & ADD & SCA & UQ & Southwestern Mandarin & $1 / 40$ & $2.5 \%$ \\
\hline Representation 4 & ADD & SCA & UQ & Cantonese & $1 / 40$ & $2.5 \%$ \\
\hline
\end{tabular}

(The peripheral members of each pattern, namely German of Representation 1, Italian of Representation 2 and Min [Taipei] of Representation 3 are excluded from Table 4 in order to be concise.) 
use the same form for ADD and SCA, but a separate item for UQ. In Xiang dialects, the same finding has been reported. For example, Xiao (2005: 101) states that in Changsha（長沙）, Changning（常寧）, Loudi（婁底）,Xinhua（新化） and Hengshan（衡山）, the scalar use is also expressed by an additive focus particle rather than the universal quantifier. All these cross-linguistic data strongly suggest that the concepts of universal quantification and scalar trigger are not universally connected, and chances are high that the presentation pattern of Mandarin Chinese is due to some language-specific development rather than language-universal reasons.

\section{$4 \quad$ Diachronic Evidence}

In this section, we will take a cursory look at the diachronic development of the markers for UQ and SCA in Chinese, aiming to examine the existing diachronic research evidence to see whether the development of Mandarin Chinese dou is due to language-specific reasons or due to some language-universal reasons, i.e. whether the process is mere happenstance in a particular language, or follows certain regularities that can be replicated across various languages.

Although Mandarin Chinese dou is widely studied in the synchronic perspective, discussions on historical relations between UQ dou and SCA dou have barely been touched upon. Only Zhang (2005), to the best of our knowledge, has examined the historical data and provided detailed analysis on the relations between UQ dou and SCA dou from a diachronic perspective. ${ }^{9}$

In what follows, we briefly introduce how the SCA dou derived from UQ dou as discussed in Zhang (2005).

When dou performs the function of "universal quantification", it demonstrates that a certain property/ action is satisfied by every member of the quantified plural arguments. In certain historical periods of Chinese, the plural arguments that appear in the subject position could be linked by a conjunction derived from a verb, like the word lian ( 連 ) 'plus, to connect.' In this case, the whole structure takes the form of "NP1 lian $\mathrm{NP}_{2}$ dou VP". Historical records show that it is from this structure that the scalar trigger dou was derived (Zhang 2005).

As suggested by Zhang (2005), after dou had developed the function of universal quantifier, the quantified components might take diversified forms. The "NP1 lian $\mathrm{NP}_{2}$ dou VP" is one of them, where "NP1 lian NP2" literally means "the first thing, plus the second." (12), (13) and (14) are examples from classical novels written in Early Mandarin:

面煩連項都有疤痕。( (《水滸傳》 第69回 $)$
miànjiáng dián dōu yǒ u bāhén
face connect with neck Dou have scar
'There are scars all across the face and the neck.'

The verbal status of lian may still be retained in the above sentence, and dou acts to quantify the two arguments: "the face" and "the neck." However, the two arguments do not carry the same weight semantically; that is to say, "the scars" exist primarily in "the face," and reach "the neck" as a supplement location.

9 There are of course a lot more diachronic studies on Chinese dou, as discussed in Yang (1998), Ge (2005), Peyraube (2006) and $\mathrm{Gu}$ (2015). However, these pieces of research show how the UQ dou came into being, and what is the relation between dou as a universal quantifier and dou as modal adverb expressing the meaning of "completely," which we can harmlessly ignore here. 
$\mathrm{Hu}$ and Shi (2007: 76) also point out that "compared with $\mathrm{NP}_{1}$, the connected $\mathrm{NP}_{2}$ is mostly secondary to the speaker.... $\mathrm{NP}_{2}$ is often the unexpected or unconventional object to the speaker." Therefore, $\mathrm{NP}_{2}$ is more informative than $\mathrm{NP}_{1}$. When $\mathrm{NP}_{1}$ and $\mathrm{NP}_{2}$ differ in the degree of informativeness, they are located at different points in the "scalar model," which may easily trigger the pragmatic inference that we have discussed in the introductory part of the "scalar trigger" section. Therefore, due to the higher degree of informativeness provided by $\mathrm{NP}_{2}$ " "lian $\mathrm{NP}_{2}$ dou VP" could entail "NP ${ }_{1}$ lian $\mathrm{NP}_{2}$ dou VP" from the perspective of pragmatic inference. Driven by the motivation of economy, the more concise form "lian $\mathrm{NP}_{2}$ dou $\mathrm{VP}$ " wins out over the complete form "NP ${ }_{1}$ lian $\mathrm{NP}_{2}$ dou VP", giving rise to a new structure, i.e., "lian $\mathrm{NP}_{2}$ dou VP." For instance:

連我腳上穿的鞋都不見了。(《金瓶梅》第 28回 $)$
lián wǒ jiăo shàng chuān de xié dô bu buàn le
including 1sG foot on wear AUX shoe DOU NEG see SFP
'Even the shoes on my feet are not seen any more.'

With the frequent use of the structure "lian $\mathrm{NP}_{2}$ dou VP," the pragmatic mechanism of labeling the most unexpected object to trigger the scalar inference is absorbed by dou. Therefore, the structure "NP ${ }_{2} d o u$ VP" could independently express this inference with or without lian. As a result, the surface structure is further condensed by omitting lian, and at this point the scalar trigger dou comes into being. ${ }^{10}$

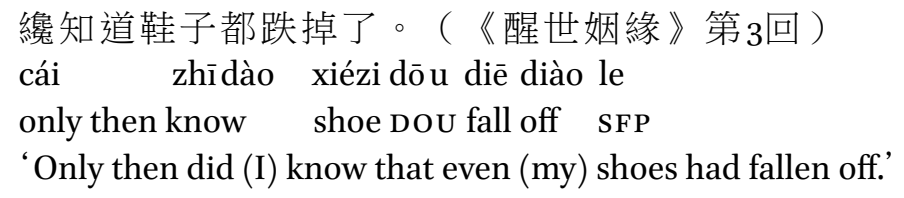

From the above diachronic process, we find that there were two reanalysis operations in the development from UQ dou to SCA dou. During the reanalysis processes, the surface structure has been changed twice. In the first change, NP1 was omitted and lian has undergone a grammaticalization from a conjunction to a preposition; in the second change, lian is omitted and the scalar meaning was shifted from the whole structure lian ... dou to the individual word dou.

The above-mentioned fine-grained diachronic analysis has widely been accepted in Chinese linguistics. Besides, as it is an independent study from our research, it serves as neutral evidence for us to conclude that the development from UQ dou to SCA dou can only be a language-specific phenomenon, because we cannot expect other languages to perform the same two omitting operations exactly as that of Chinese.

In fact, it is a prevalent fact in the field of typology that in most languages of the world, the scalar additive particles are mostly derived from the additive particles (König 1991, Gil 2004). So far, we have not found any reports in other languages which claim a universal quantifier has developed into an additive scalar function.

To further demonstrate why this language-specific change from UQ dou to SCA dou proves the two-dou claim, a reverse example explaining how language-universal change proves conceptual correlation is employed in the following discussion. Consider the example of English have to as shown in example (15). 
(15) A: Ingrid has to arrive before we do (because she promised to help with the preparations). B: Ingrid has to arrive before we do (because she set out an hour earlier). (Bybee and Pagliuca 1985: 74)

As is shown, have to can sometimes be ambiguous. In sentence $(15 \mathrm{~A})$, it produces an obligation reading which is known as "deontic" modality; while in sentence $(15 \mathrm{~B})$, it is compatible with an epistemic reading and known as "epistemic" modality. Bybee and Pagliuca (1985: 73) examined the historical data and argued that "the epistemic sense is a metaphorical extension of obligation to apply to the truth of a proposition: $\mathrm{X}$ (a proposition) is obliged to be true."

"Metaphorical extension," as stated above in the semantic change from deontic have to to epistemic have to, is usually deemed as a conceptual phenomenon, and thus often termed as "conceptual metaphorization" (Traugott and Dasher 2001: 29). If we compare the conceptual metaphorization process of English have to with the reanalysis process of Chinese dou, two major differences can be detected. (1) The metaphorization process of have to is at the conceptual level whereas the reanalysis process of dou entails operations on the surface structure. (2) The reanalysis of dou involves processes of loss, while the grammaticalization of have to is mainly an extension from one conceptual domain to another conceptual domain without formal loss. If we put these two semantic change processes into a cross-linguistic canvass, it is easy to infer that the metaphorization process, like that of have to, is more likely to be a cross-linguistic phenomenon; while the reanalysis process, like that of $d o u$, is less likely to be observed across different languages. The reason is that different languages are comparable at the conceptual level but not at the structural level. Besides, as "loss is unpredictable and irregular" (Traugott and Dasher 2001: 39), the reanalysis process, such as that of dou which involves two operations of structural loss, is hard to be replicated across languages.

In fact, that metaphorization works as a language-universal grammaticalization mechanism has long been verified. By reviewing the theoretical issues, Traugott and Dasher (2001: 75) stated that research on metaphor, or the metaphorization process, actually starts from cross-linguistic studies, like Greenberg, Ferguson and Moravcsik (1978). So far, we have analyzed that metaphorization can be cross-linguistic. In the following, we will employ historical syntax and grammaticalization studies across different languages on the field of modality to verify that a metaphorical process, such as that of have to, is indeed a crosslinguistic phenomenon. Throughout the recorded history of Chinese, we find lots of language forms similar to English have to which can express both the meaning of obligation and epistemic possibility. Sun (1996) and Yin (2014) examined the history of de (得 ） and dang (當）, and concluded that both of these two forms developed their epistemic meaning from the deontic meaning. Yin (2014: 204) also analyzed how metaphor plays a part in the grammaticalization process. Apart from English and Chinese, many language forms in other languages can also perform both obligation and epistemic possibility. By examining 25 languages in the world, Bybee and Pagliuca (1985) generalized a cross-linguistic tendency that the obligation sense precedes the epistemic sense, and it is also clearly demonstrated that metaphorical extension is one of the important mechanisms in generalization.

The semantic change from "deontic" to "epistemic" recurs so often and across totally unrelated languages that such regularity is by no means an accident; it proves that deontic and epistemic are intrinsically bound, i.e. deontic and epistemic have universal conceptual correlations. Typological studies at the synchronic level have also proved this (Van der Auwera and Plungian 1998). This kind of typological finding can provide insights on many issues, including those that cannot be easily solved by a languagespecific perspective. In this sense, if we are required to evaluate the relation between deontic dang and epistemic dang in Chinese, the answer is evident that they should be subsumed under one category. 
By the above contrast between Chinese dou and English have to, we have illustrated how the diachronic semantic change of dou confirms the language-specific property of the connections between UQ dou and SCA dou, which again verifies the synchronic conclusion of the two-dou claim.

So far, the synchronic analysis, the cross-linguistic comparison and the diachronic development of dou all point to the same conclusion: the notions UQ and SCA are not universally connected. The behavior of Mandarin Chinese dou in employing the same form to denote these two notions is proved to be language-specific, which arises from an unusual reanalysis in the development. Therefore, UQ dou and sCA dou should be deemed as two different representations.

\section{$5 \quad$ The Categorization of $\mathrm{Dou}$}

The reason why the categorization of dou has caused much controversy in Chinese linguistics is that the UQ function and the SCA function are a pair of conceptually different but pragmatically related functions. In the above we have proved from various perspectives that these two functions lack a universal connection; therefore, UQ dou should be recognized as distinct from SCA dou. In the following, we will present why the opposite one-dou-claim is problematic.

In the literature on $d o u$, pragmatic theories are often evoked to provide a solution for inferring a UQ reading from the SCA use. Jiang $(1998,2009,2011)$ and Xiang (2008) have illustrated from the perspectives of "scalar model" and "pragmatic scale" that scalar dou induces an ordered sequence of a set. By pointing to the member that is located at the end point of this scale, the dou sentence entails that the members that are located higher (or lower depending on the specific context) on the scale will all have the property as the scalar member that dou marks. That is how it connects to the UQ reading. To illustrate this point, Xiang (2008: 227) provides the following example:

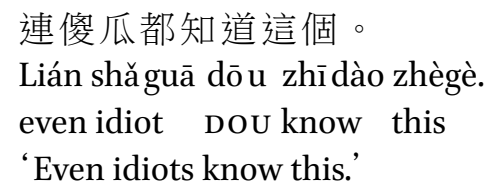

Xiang indicates that "speakers can accent on the word idiot to emphasize on the intended message that everybody knows how to do it." (ibid) However, in our opinion the scalar dou sentence does not intend to emphasize the universal quantification reading that "everybody" knows something. Instead, it is used to emphasize a specific member that is higher on this scale (most likely the reference is the listener in the conversation), in comparison to the scalar member - the "idiot," is more likely to know this. A more explicit example that supports our account is from Xiao (2005: 99), which is also cited in Jiang (2011: 452).

(17) A: 你知道活字印刷的發明者是誰嗎?

nǐ zhī dào huó zì yìnshuā de fāmíngzhě shì shéi ma 2SG know movable type printing AUX inventor COP who SFP

'Do you know who is the inventor of the movable type printing?'

B: 小學生都知道。

xiǎ oxuéshēng dōu zhī dào

pupil even know

'Even a pupil knows this.' 
小學生都知道（活字印刷的發明者是誰）,

xiă oxuéshēng dōu zhīdào (huó zì yìnshuā de fāmíngzhě shì shéi)

pupil even know movable type printing AUX inventor COP who

'Even a pupil knows who is the inventor of the movable type printing.'

(我知道的比小學生知道的多),

(wǒ zhīdào de bǐ xiǎoxuéshēng zhīdào de dūō)

1SG know AUX CM pupil know AUX more

'What I know is more than what a pupil knows,'

(所以, 我當然知道活字印刷的發明者是誰)。

(suǒ y̌̌, wǒ dāngrán zhīdào huó zì yìnshuā de fāmíngzhě shì shéi)

therefore 1SG sure know movable type printing AUX inventor COP who

'Therefore, of course I know who is the inventor of the movable type printing.'

The above instance clearly demonstrates that there is a syllogistic chain which lets us attain the pragmatic inference of dou. In this syllogistic chain, "pupil" is set as an extreme member of the scale, from which the property of another particular member on the scale (the reference is "I" in the above utterance) is deduced. Therefore, it is not the whole complementary set of \{pupil\} that is focused; instead, it is a particular intended member in the complementary set that is in focus. In this sense, we can find that the SCA dou is still an existential operator in nature, and it is different from the UQ dou. Therefore, we do not think it suitable to regard SCA as a pragmatically reinforced subtype of UQ.

Based on the evidence from synchronic data and a diachronic survey, we have demonstrated that UQ and SCA lack a universal conceptual correlation and the semantic derivation of dou from UQ to SCA is due to a particular reanalysis process. Therefore, no direct conceptual correlation exists between dou that expresses the UQ function and dou that expresses the SCA function. Besides, we have also demonstrated from the opposite angle that it is inappropriate to see SCA as a special case of UQ as the focus of the SCA expression is a particular member on the scale rather than the whole set. In these two approaches, we prove that the UQ dou and the SCA dou should be regarded as two distinct dous in Chinese.

\section{Discussion}

In this research, we have provided an account for the long-standing puzzle about how many dous there are in Mandarin Chinese and how the different functions of dou are conceptualized in the same language. Based on the first-hand data from 40 languages, we show that employing the same form for UQ and SCA is an exclusive phenomenon in Mandarin Chinese. No other language or dialect exhibits the same behavior. The empirical data strongly suggests that UQ dou and SCA dou are different. This claim is further supported by the diachronic development of $d o u$, from which we argue that dou absorbs the scalar semantics through two reanalysis processes and this change is highly language-specific rather than language-universal.

The process of identifying the uniqueness of Mandarin dou has also demonstrated the advantage of a cross-linguistic comparison. In fact, only by fully understanding universality shared by different languages can one best recognize the particularity in specific language. The cross-linguistic comparison is just one of the best candidates to cater for this goal. Besides, this perspective can also help us evaluate existing proposals and even make predictions for future work. From the cross-linguistic perspective, we can tell whether or not a generalization is at the right level of generality. As pointed out by Haspelmath (1997: 7), "cross-linguistic studies can help steer us through the Scylla of overgeneralization and the 
Charybdis of undergeneralization." Sometimes one is prone to explain a language-particular phenomenon by a high-level generalization. Alternatively, one may erroneously invoke a low-level generalization to account for a language-universal phenomenon. With a cross-linguistic perspective, however, we can avoid this kind of wrong prediction. If the cross-linguistic data converge to show a common regularity, we may seek to account for it based on universal factors; on the other hand, if a phenomenon is only found in an individual language, then a particular explanation is called for (ibid). In this sense, the crosslinguistic exploration on dou as shown above can also predict if on-going research is on the right track. For instance, an account at the language-specific level is believed to be the more fruitful direction than its counterpart for research inquiries that involve the relation of UQ dou and SCA dou.

Apart from the uniqueness of Mandarin Chinese dou, Cantonese dou is also identified to present very rare semantic behaviors. Cantonese dou can not only deliver the functions of UQ and sCA by one form, but also it can express the function of ADD as well. Naturally, we may raise a question about the origin of this ADD function. Does it reflect a natural semantic extension, or is it merely a stand-in for the vanished ye in Cantonese? Szabolcsi, Whang and Zu (2014:148) pose a similar query: "We do not know whether the gap in Mandarin is due to the blocking effect of $y e$ 'also, even' or, conversely, dou spills over to fill a vacant spot in the absence of ye in Cantonese." However, no further discussion is offered in their research. Peng and Chen (2010: 109) argue that Cantonese dou expressing additive focus is a rather recent phenomenon, and it is derived from the universal quantification use of $d o u$. However, this derivation is admitted by the authors to be uncommon, as it deviates from the widely accepted mechanisms of grammaticalization. Apart from Cantonese $\mathrm{dou}$, we have also found a parallel circumstance in a reference grammar of the Lachi language ( $\mathrm{Li}$ 2000), where it is shown that $l a^{31}$ can also express the three concepts all by itself. However, evidence is insufficient for us to tell whether this circumstance is due to conceptual correlation or simply a historical incident induced by non-conceptual factors. We believe this line of inquiry deserves further pursuit.

\section{Acknowledgements}

I would like to express my sincere gratitude to Professor Min Zhang, who patiently supervised me in this project. I also thank two anonymous reviewers for their thoughtful comments and suggestions on earlier versions of it. Of course, all the remaining errors are mine. The work has been supported by Hong Kong Research Grants Council (Project No. 641913).
Abbreviations

$1 \quad$ first person

2 second person

3 third person

ADD additive focus

AUX auxiliary

CLF classifier

$\mathrm{CM}$ comparative marker

COP copula

N.SCA NPI scalar trigger

NEG negative

NPI negative polarity item 


$\begin{array}{ll}\text { P.SCA } & \text { PPI scalar trigger } \\ \text { PFV } & \text { perfective } \\ \text { PL } & \text { plural } \\ \text { PPI } & \text { positive polarity item } \\ \text { PRT } & \text { particle } \\ \text { SCA } & \text { scalar trigger } \\ \text { SFP } & \text { sentence final particle } \\ \text { SG } & \text { singular } \\ \text { UQ } & \text { universal quantification }\end{array}$

\section{References}

Bybee, Joan L., and William Pagliuca. 1985. Cross-linguistic comparison and the development of grammatical meaning. Historical Semantics and Historical Word Formation, ed. by Jacek Fisiak, 59-83. Berlin: Mouton.

Chen, Liping. 2008. Dou: Distributivity and Beyond. Ph.D. dissertation, the State University of New Jersey.

Cheng, Lisa Lai-shen. 1995. On dou-quantification. Journal of East Asian Linguistics 4: 197-234.

Fillmore, C.J., P. Kay, and M.C. O' Connor. 1988. Regularity and idiomaticity in grammatical constructions: The case of let alone. Language 64: 501- 538 .

Gast, Volker and Johan van der Auwera. 2011. Scalar additive operators in the languages of Europe. Language 87.1: 2- 54.

Ge, Jiacai. 葛佳才. 2005. 《東漢副詞系統研究》。長沙 : 岳麓書社.

Gil, David. 2004. Riau Indonesian sama: Exploration in macro functionality. Coordinating Constructions, ed. by Martin Haspelmath, 371-426. Amsterdam/Philadelphia: Benjamins.

Greenberg, Joseph H., Charles A. Ferguson and Edith Moravcsik. (eds.) 1978. Universals of Human Language. Stanford: Stanford University Press.

Gu, Feng. 谷峰. 2015. 〈“都” 在東漢有沒有語氣副詞的用法?〉, 《中國語文》3: 230-239.

Haspelmath, Martin. 1997. Indefinite Pronouns. Oxford: Oxford University Press.

Hu, Xiaoping and Jinsheng Shi. 胡曉萍 史金生. 2007. 〈連類介詞的語法化〉, 《語法化與語法研究》（三）: $65^{-85}$.

Jiang, Jing. 蔣靜. 2003. 〈“都”總括全量手段的演變及其分類〉，《漢語學習》4: 72- 76 .

Jiang, Yan. 蔣嚴. 1998. 〈語用推理與“都”的句法語義特徵〉, 《現代外語》1: 10-24.

Jiang, Yan. 蔣嚴. 2009. 〈梯級模型與 “都” 的語義刻畫〉, 程工、劉丹青主編《漢語的形式與功能研究》, 123-132。北京：商務印書館.

Jiang, Yan. 蔣嚴. 2011.〈“都” 的形式語用學〉, 蔣嚴主編《走進形式語用學》：432-456。上海：上海教育 出版社.

Jiang, Jingzhong and Haihua, Pan. 蔣靜忠 潘海華. 2013. 〈都的語義分合及解釋規則〉, 《中國語文》1: $3^{8}-50$. König, Ekkehard. 1991. The Meaning of Focus Particles. London/New York: Routledge.

Lee, Thomas Hun-tak. 1986. Studies on Quantification in Chinese. Ph.D. dissertation, University of California, Los Angeles.

Li, Wenshan. 李文山. 2013. 〈也論 “都” 的語義複雜性及其統一刻畫〉, 《世界漢語教學》3: 319-330.

$\mathrm{Li}$, Yunbing. 李雲兵. 2000. 《拉基語研究》。北京 : 中央民族大學出版社.

Ma, Zhen. 馬真. 1982.〈說 “世” 〉, 《中國語文》4:283-287.

Matthews, S. and V. Yip. 1994. Cantonese: A Comprehensive Grammar. London and New York: Routledge.

Pan, Haihua. 潘海華. 2006. 〈焦點、三分結構與漢語 “都” 的語義解釋〉, 《語法研究與探索》（十三）。 北京：商務印書館. 
Peng, Xiaochuan and Qiping Chen. 彭小川 陳啟萍. 2010. 〈廣州話 “類同義”副詞歷時演變的特點與機制〉， 《暨南學報（哲學社會科學版）》3: 105-109.

Peyraube, Alain. 2006. On the history of some adverbs of scope and quantity in Chinese, Studies in Chinese Language and Culture: Festschrift in Honor of Christoph Harbsmeier on the Occasion of His 6oth Birthday, eds. by Christoph Anderl and Halvor Eifring, 269-283. Oslo: Hermes Academic Publishing.

Shank, Scott. 2004. Domain Widening. Ph.D. dissertation, Vancouver: The University of British Columbia.

Shen, Jiaxuan. 沈家煊. 2015. 〈走出都的量化迷途：向右不向左〉, 《中國語文》1: $3^{-17}$.

Sun, Chaofen. 1996. Word Order Changes and Grammaticalization in the History of Chinese. Stanford: Stanford University Press. Szabolcsi, A., J.D. Whang, and V. Zu. 2014. Quantifier words and their multi-functional parts. Language and Linguistics 15.1: $115^{-155}$.

Traugott, Elizabeth C. and Richard B. Dasher. 2001. Regularity in Semantic Change. Cambridge: Cambridge University Press. van der Auwera, Johan and Vladimir A. Plungian. 1998. Modality's semantic map. Linguistic Typology 2.1: 79-124.

Wang, Hong. 王紅. 1999. 〈副詞“都” 的語法意義試析〉, 《漢語學習》6: 55-60.

Wang, Hong. 王紅. 2001. 〈語氣副詞 “都” 的語義、語用分析〉, 《暨南大學華文學院學報》2: 41-45.

$\mathrm{Wu}$, Haiping and Hongyin Tao. 2014. Doing generalizations in Mandarin conversation: The case of plural NP+dou expression.

Paper presented at the $2^{\text {nd }}$ Annual Conference of the American Pragmatics Association, October 17-19, LA.

Xiang, Ming. 2008. Plurality, maximality and scalar inference: a case study of Mandarin dou. Journal of East Asian Linguistics 17.3: $227-245$.

Xiao, Shuangrong. 肖雙榮. 2005. 〈“都” 的全稱量項義與隱含差比義〉, 《湖南人文科技學院學報》6: 98-104.

$\mathrm{Xu}$, Liejiong. 徐烈畑. 2014. 〈“都” 是全稱量詞嗎?〉, 《中國語文》6: 498-575.

Yang, Rongxiang. 楊榮祥.1998. 〈總括副詞“都”的歷史演變〉，《北大中文研究》1:311-332.

Yin, Chunyi. 尹淳一. 2014. 〈“祖堂集”情態動詞及其語法化研究〉，復旦大學博士論文.

Zhang, Yisheng. 張誼生. 2005. 〈副詞 “都” 的語法化與主觀化一兼論 “都” 的表達功用和內部分類〉, 《徐州師範大學學報（哲學社會科學版）》1: 56-62. 


\title{
跨語言視域下現代漢語「都」的分類
}

\author{
張瑩
}

哈爾濱工業大學（深圳）人文與社會科學學院

yingzhang@hit.edu.cn

\section{摘要}

與其他世界語言中典型的全稱量詞相比, 漢語普通話里的「都」有更為複雜的語義表現。長期以來, 普通 話中表全量的「都」與表極端的「都」之間的關係始終是學界爭論的焦點之一。來自世界語言中不同語系 的 40 種語言的一手調查資料顯示, 普通話是這40種語言中唯一一個用同一語法形式來表達（且僅表達）

$\ulcorner$ 全量」和「極端」這兩個概念的語言。這一發現說明 $「$ 全量」與「極端」這兩個概念之間在很大程度上 並不存在跨語言普遍存在的概念關聯。除了共時類型學的材料之外, 歷時語法化的研究成果也驗證了表全 量的「都」發展出表極端的「都」只是特定语言在形式层面重新分析的特定的语法化现象。由於跨語言層 面上 $「$ 全量」與「極端」缺乏普遍概念關聯，以及全量 $「$ 都」到極端「都」語言演化過程的特定性，普通 話中全量 $「$ 都」與極端「都」應當視為不同的兩個「都」。通過對普通話「都」這一個例的探討，文章進 一步指出了跨語言視角在解決單一語言內部問題上的功用, 即在面對一些長期未能解決的問題上, 跨語言 視角可以輔助避免過度概況和不充分概括, 為做出契合的分析提供重要的參考。

\section{關鍵詞}

都、全量、極端、跨語言比較 